\title{
Resistance of melon cultivars to Bemisia tabaci biotype B
}

\author{
Edson LL Baldin; José Paulo GF da Silva; Luiz Eduardo R Pannuti
}

UNESP-FCA, Depto. Prod. Vegetal (LARESPI), 18610-307 Botucatu-SP; elbaldin@fca.unesp.br; jpsilva@fca.unesp.br; luizpannutixl@ yahoo.com.br

\begin{abstract}
The silverleaf whitefly, Bemisia tabaci biotype B, is currently one of the most important pests of melon, causing direct and indirect damage to plants, and significantly reducing production in the field. Due to the need for alternative methods of chemical control in melon crops, the melon cultivars AF-646, AF-682, Don Luis, Frevo, Jangada, Nilo, Vereda, Amarelo Ouro and Hales Best were assessed at field, greenhouse, and laboratory trials for resistance to whitefly $B$. tabaci biotype B. In general, 'Hales Best' and 'Amarelo Ouro' were the most resistant, showing oviposition non-preference against whitefly. The trichome density is associated with the variation in oviposition on the cultivars and should be further investigated in future work. These results may be helpful in melon breeding programs, focusing on plant resistance to $B$. tabaci biotype $\mathrm{B}$.
\end{abstract}

Keywords: Cucumis melo, Aleyrodidae, silverleaf whitefly, host plant resistance, antixenosis, antibiosis.

\section{RESUMO}

Resistência de cultivares de melão a Bemisia tabaci biótipo $\mathrm{B}$

A mosca-branca, Bemisia tabaci biótipo B, é atualmente uma das mais importantes pragas da cultura do melão, ocasionando danos diretos e indiretos às plantas e reduzindo significativamente as produções a campo. Devido à necessidade de métodos mais sustentáveis do que o controle químico nas lavouras de melão, neste trabalho avaliou-se a resposta das cultivares de meloeiro AF-646, AF-682, Don Luis, Frevo, Jangada, Nilo, Vereda, Amarelo Ouro e Hales Best quanto à possível resistência a $B$. tabaci biótipo $\mathrm{B}$, através de testes de campo, casa de vegetação e laboratório. No geral, 'Hales Best' e 'Amarelo Ouro' foram as mais resistentes, expressando não-preferência para oviposição contra a mosca-branca. A densidade de tricomas está associada à variação de oviposição sobre os materiais e deve ser melhor investigada em trabalhos futuros. Estes resultados podem auxiliar nos programas de melhoramento de melão, visando à resistência de plantas a $B$. tabaci biótipo $\mathrm{B}$.

Palavras-chave: Cucumis melo, Aleyrodidae, mosca-branca, resistência de plantas a insetos, antixenose, antibiose.

(Recebido para publicação em 27 de outubro de 2011; aceito em 3 de agosto de 2012)

(Received on October 27, 2011; accepted on August 3, 2012)

$\mathrm{T}$ he melon (Cucumis melo) is a commercially important vegetable, adaptable to several types of soils and climate, and can be grown in several regions of the world (FAO, 2006). Brazil is one of the largest melon producers in South America, producing 340,464 $\mathrm{t}$ in 15,756 cropped hectares (Agrianual, 2011).

The silverleaf whitefly, B. tabaci biotype $\mathrm{B}$, has been indicated as one of the most serious pests of world agriculture, causing losses of millions of dollars per year (Perring et al., 1993; Polston \& Anderson, 1999). This insect has recently become the most important pest for melon cropping in several Brazilian states (Azevedo \& Bleicher, 2003). Its attack causes direct damage by continuous sucking of plant xylem (Bleicher et al., 2000) and also indirect damage, such as silverleaf(Lourenção et al., 2011), sooty mold development and virus transmission (Nagata et al., 2005), that reduce productivity. The increase in the total number of whitefly nymphs in melon fields is directly related to the fall in weight and number of boxes harvested, in addition to reduced product end quality due to the presence of sooty mold and decreases in fruit size and total soluble solids content (Riley \& Palumbo, 1995).

The strategy most used to control B. tabaci biotype B is still the use of chemical insecticides (Mansaray \& Sundufu, 2009) but this practice is considered high risk for beneficial arthropods and the environment, encouraging the search for more sustainable management methods (Desneux et al., 2007). Allied to this, biological and behavioral characteristics of the insect, such as fast development, high fertility and wide dispersion capacity, increase the probability of selecting individuals resistant to the most used insecticides that decreases their efficiency in the short term (Prabhaker et al., 1989; Dittrich \& Ernest, 1990;
Dardon, 1993; Byrne et al., 2003).

In this context, the use of resistant genotypes to $B$. tabaci biotype B could be an efficient control alternative (Alves et al., 2005; Baldin et al., 2005; Bleicher et al., 2007; Silva et al., 2008; Baldin \& Pereira, 2009; Baldin \& Beneduzzi, 2010). Its advantages include efficiency, low cost and compatibility with other control tactics (Lara, 1991). Thus, the present study assessed the performance of melon cultivars under $B$. tabaci biotype $B$ attack in the field, greenhouse and laboratory to identify possible sources of resistance against the insect.

\section{MATERIAL AND METHODS}

The study was carried out under field conditions (22 $53^{\circ} 09^{\prime}$ 'S, $48^{\circ} 26^{\prime} 42^{\prime \prime} \mathrm{W}$, $804 \mathrm{~m}$ altitude), in a greenhouse, and in the laboratory, from 2008 to 2009. Nine melon cultivars were assessed: AF-646, AF-682, Don Luis, Frevo, Jangada, Nilo, Vereda (from Sakata) and Amarelo 
Ouro and Hales Best (from Top Seed).

\section{B. tabaci biotype $B$ rearing -} Whiteflies were reared in metallic cages $(2.0 \times 2.5 \times 2.0 \mathrm{~m})$ with sides lined with white anti-aphid screening, and the top was covered by plastic and shade cloth. Benches were placed inside to accommodate the pots containing collard green plants, that served as a food source for the insect. The pots were monitored and deteriorated plants exchanged for healthy ones weekly.

To start the rearing, adult whiteflies were acquired from a rearing center kept at the Plant Pathology Center at the Campinas Agronomic Institute [Centro de Fitossanidade do Instituto Agronômico de Campinas (IAC)], that had been recently characterized molecularly as belonging to $B$. tabaci biotype B (Fontes et al., 2010).

Field trial - The nine melon cultivars were sown in four rows spaced $1.0 \mathrm{~m}$ with 0.70 between-plant spacing. The plots consisted of four planting rows, measuring $4 \times 4\left(16 \mathrm{~m}^{2}\right)$ following a randomized block design with four replications. The assessments were made on the plants of the two central lines of the crop.

The attractiveness and oviposition on the genotypes were assessed four times, first at 30 days after plant emergence (DAE) when the plants presented 6-8 completely developed leaves, and later at 45, 60 and 75 DAE. The attractiveness was assessed by counting the number of adult whiteflies on the abaxial surface of three leaves (upper, mid and lower strata) of a plant of each cultivar, using a portable mirror positioned on the abaxial surface of the melon leaves so that the insects could be counted without contact with the plants (Baldin \& Pereira, 2009). After counting the adults on the three leaves, the leaves were removed from the plants and taken to the laboratory to count the eggs and nymphs present in $2 \mathrm{~cm}^{2}$, under a stereomicroscope. All the assessments were carried out in the morning (before 9 AM) when the insects presented less migratory activity.

Trials in the greenhouse - The same genotypes assessed in the field were also used in the trials in the greenhouse. In a free-choice test, nine 1-L pots (one for each cultivar) containing 20-day-old plants (with two completely developed leaves) were distributed randomly in a circle inside a wooden cage $(1.0 \mathrm{x}$ $1.0 \times 0.8 \mathrm{~m}$ ), lined on the side and top with anti-aphid screening. Later, 450 whitefly couples up to 48 hours old were released on the floor and center of the cage. The attractiveness was assessed 24 and 48 hours after infestation, counting with the help of a mirror the number of insects present on the two leaves of each genotype. After five days infestation, the leaves assessed for attractiveness were removed and taken to the laboratory, to count the eggs in $2 \mathrm{~cm}^{2}$ of the abaxial surface of each one, as described for the field trial. Each cage represented one replication, six in total, in a randomized block design.

For the no-choice test, pots containing 20-day-old plants were separated and metal arches were attached covered with organdy fabric (Baldin et al., 2005). Later, fifty 48h-old whitefly couples were released per pot and infestation maintained for five days. Oviposition was assessed following the same methodology described for the no choice test. However, in this case a complete randomized design was adopted, with six replications.

For the free-choice and no-choice tests, the oviposition preference index was also determined: $\mathrm{OPI}=[(\mathrm{T}-\mathrm{S}) /$ $(\mathrm{T}+\mathrm{S})] \times 100$, where $\mathrm{T}=$ number of eggs counted in the treatment assessed and $\mathrm{S}=$ number of eggs counted on the control cultivar (Jangada). The index ranged from +100 (very stimulating) to -100 (total deterrence), and the value 0 indicated neutrality (Fenemore, 1980; Schilick-Souza et al., 2011). The Jangada cultivar was adapted as control because it was highly susceptible in preliminary trials. The mean standard error of the trial was used to classify the materials (Baldin et al., 2005).

Trichome analysis - To correlate oviposition with melon plant morphological factors, the number of trichomes present in 16 $\mathrm{mm}^{2}$ of the abaxial surface of the leaves of each material was counted using a stereomicroscope, with $32 \mathrm{x}$ magnification (Valle \& Lourenção, 2002). The first two true leaves of each cultivar were analyzed, dividing them in two $16 \mathrm{~mm}^{2}$ plots per leaf. Four replications were made in a completely randomized design.

Laboratory trial - The B. tabaci biotype B egg-adult cycle on the different melon cultivars was assessed in the laboratory $\left(25 \pm 2{ }^{\circ} \mathrm{C} ; 70 \pm 10 \% \mathrm{RH}\right.$; $12: 12 \mathrm{~L}: \mathrm{D})$ to verify whether there was non-preference for food and/or antibiosis. The materials were sown in $2 \mathrm{~L}$ pots containing adequate substrate and remained infestation-free until 20 DAE. Then two leaves/plant (first true leaves) were separated attaching organdy cloth cages and 25 couples of the insect were released inside each one. The insects were removed after 24 hours, maintaining 30 eggs (circled with glitter glue) on the abaxial surface of each leaf. In the assessments, two pots per cultivar were used and each leaf was considered a replication (four per genotype), containing 30 plots (eggs) each, in a completely randomized design. Assessments were made daily, observing the incubation period, the nymph instar duration and the egg to adult development period. When the emergence period of the adults was close, the leaves were again covered with organdy fabric cages, so that the insects could not leave the leaves.

All the data obtained during the trials were submitted to the Kolmogorov \& Barttlet test for normality and homogeneity of variance, respectively, and the necessary transformations were made to meet the requirements of the analysis of variance (Winer et al., 1991). The means were compared by the Tukey test at the level of 5\% probability, using the Sisvar statistical program.

\section{RESULTS AND DISCUSSION}

Field trial - In the field, the 'AF646', 'Vereda', 'Don Luis', and 'Hales Best' were the least attractive to $B$. tabaci biotype B adults, unlike 'Jangada' that was preferred by most of the adults (Figure 1). The low attractiveness of these four cultivars suggested there was non-preference against whitefly. However, as the B. tabaci biotype B field infestations were not high (maximum 2.1 individuals/plant), the material may perform differently under high 
Table 1. Mean $( \pm \mathrm{SE})$ of attractivity, eggs per $\mathrm{cm}^{2}$ and oviposition preference index of $B$. tabaci biotype B in free-choice test conducted in greenhouse (médias ( $\pm \mathrm{EP}$ ) de atratividade, ovos por $\mathrm{cm}^{2}$ e índice de preferência para oviposição (IPO) de $B$. tabaci biótipo B em teste com chance de escolha realizado em casa-de-vegetação). Botucatu, UNESP, 2008/2009.

\begin{tabular}{|c|c|c|c|c|c|}
\hline \multirow{2}{*}{ Cultivar } & \multicolumn{2}{|c|}{ Number of adults ${ }^{1}$} & \multicolumn{3}{|c|}{ Oviposition } \\
\hline & $24 \mathrm{~h}$ & $48 \mathrm{~h}$ & number of eggs ${ }^{1}$ & $\mathrm{OPI}( \pm \mathrm{SE})^{2}$ & $\overline{\mathrm{Cl}^{2}}$ \\
\hline Hales Best & $5.94 \pm 1.93 \mathrm{~b}$ & $5.25 \pm 1.54 \mathrm{~b}$ & $10.94 \pm 0.95 \mathrm{ab}$ & $-33.06 \pm 7.95$ & $\mathrm{D}$ \\
\hline Nilo & $13.06 \pm 4.89 \mathrm{ab}$ & $12.06 \pm 4.70 \mathrm{ab}$ & $12.50 \pm 1.27 \mathrm{ab}$ & $-27.00 \pm 7.95$ & $\mathrm{D}$ \\
\hline Amarelo Ouro & $14.38 \pm 4.79 \mathrm{ab}$ & $12.44 \pm 4.54 \mathrm{ab}$ & $4.50 \pm 0.48 b$ & $-65.71 \pm 7.95$ & $\mathrm{D}$ \\
\hline Don Luis & $16.13 \pm 4.79 \mathrm{ab}$ & $15.56 \pm 3.82 \mathrm{ab}$ & $11.06 \pm 0.79 \mathrm{ab}$ & $-32.58 \pm 7.95$ & $\mathrm{D}$ \\
\hline AF-646 & $18.94 \pm 5.64 \mathrm{ab}$ & $20.44 \pm 5.49 \mathrm{ab}$ & $17.44 \pm 2.20 \mathrm{a}$ & $-10.99 \pm 7.95$ & $\mathrm{D}$ \\
\hline Vereda & $24.75 \pm 10.37 \mathrm{ab}$ & $23.94 \pm 9.81 \mathrm{ab}$ & $18.06 \pm 1.75 \mathrm{a}$ & $-9.26 \pm 7.95$ & $\mathrm{~N}$ \\
\hline Frevo & $27.81 \pm 9.15 \mathrm{ab}$ & $29.88 \pm 10.34 \mathrm{a}$ & $13.94 \pm 0.87 \mathrm{ab}$ & $-21.88 \pm 7.95$ & $\mathrm{D}$ \\
\hline AF-682 & $28.63 \pm 8.35 \mathrm{a}$ & $35.69 \pm 13.34 \mathrm{a}$ & $18.56 \pm 2.10 \mathrm{a}$ & $-7.91 \pm 7.95$ & $\mathrm{~N}$ \\
\hline Jangada & $30.81 \pm 12.35 \mathrm{a}$ & $30.13 \pm 11.38 \mathrm{a}$ & $21.75 \pm 2.27 \mathrm{a}$ & $0.00 \pm 7.95$ & $\mathrm{~S}$ \\
\hline $\mathrm{F}$ & $2.51^{*}$ & $3.27^{* *}$ & $2.98^{* *}$ & --- & $\overline{---}$ \\
\hline CV $(\%)$ & 39.52 & 40.16 & 34.21 & --- & --- \\
\hline
\end{tabular}

${ }^{1}$ Means followed by the same letter in the column don't differ significantly, according to Tukey's test ( $\left.<<0,05\right)$; original data for analysis were transformed into $(\mathrm{x}+0,5)^{1 / 2}$ (médias seguidas de mesma letra, dentro das colunas, não diferem entre si pelo teste de Tukey ( $\left.\mathrm{p}<0,05\right)$; dados originais para análise foram transformados em $\left.(\mathrm{x}+0,5)^{1 / 2}\right) ;{ }^{2} \mathrm{OPI}=(\mathrm{T}-\mathrm{P}) /(\mathrm{T}+\mathrm{P}) \mathrm{x} 100$. Classification: $\mathrm{S}=$ standard; $\mathrm{N}=$ neutral; $\mathrm{D}=\mathrm{deterrent}$ (classificação: $\mathrm{S}=$ controle; $\mathrm{N}=$ neutro; $\mathrm{D}=$ deterrente).

Table 2. Ovipostion behaviour of $B$. tabaci biotype B, and mean number $\left( \pm\right.$ SE) of trichome $/ 16 \mathrm{~mm}^{2}$ of melon cultivars in no-choice test conducted in greenhouse (oviposição de $B$. tabaci biótipo B e número médio ( $\pm \mathrm{EP}$ ) de tricomas $/ 16 \mathrm{~mm}^{2}$ de cultivares de meloeiro, em teste sem chance de escolha realizado em casa-de-vegetação). Botucatu, UNESP, 2008/2009.

\begin{tabular}{|c|c|c|c|c|}
\hline \multirow{2}{*}{ Cultivar } & \multicolumn{3}{|c|}{ Oviposition } & \multirow{2}{*}{ Number of trichomes } \\
\hline & Number of eggs $^{1}$ & OPI $( \pm \text { SE })^{2}$ & $\mathrm{Cl}^{2}$ & \\
\hline Amarelo Ouro & $6.19 \pm 0.77 \mathrm{~d}$ & $-58.68 \pm 8.39$ & $\mathrm{D}$ & $99.00 \pm 4.42 \mathrm{~b}$ \\
\hline Hales Best & $10.44 \pm 3.65 \mathrm{~d}$ & $-43.99 \pm 8.39$ & $\mathrm{D}$ & $144.25 \pm 10.16 \mathrm{a}$ \\
\hline AF-646 & $11.88 \pm 1.46 \mathrm{~cd}$ & $-33.04 \pm 8.39$ & $\mathrm{D}$ & $99.25 \pm 2.95 b$ \\
\hline Vereda & $12.00 \pm 1.41 \mathrm{~cd}$ & $-32.95 \pm 8.39$ & $\mathrm{D}$ & $88.00 \pm 1.78 b$ \\
\hline AF-682 & $13.13 \pm 1.58 \mathrm{bcd}$ & $-28.41 \pm 8.39$ & $\mathrm{D}$ & $86.50 \pm 3.52 b$ \\
\hline Don Luis & $20.75 \pm 0.42 \mathrm{abc}$ & $-6.68 \pm 8.39$ & $\mathrm{~N}$ & $82.50 \pm 5.44 \mathrm{~b}$ \\
\hline Frevo & $23.44 \pm 2.66 \mathrm{abc}$ & $-1.63 \pm 8.39$ & $\mathrm{~N}$ & $75.50 \pm 3.48 b$ \\
\hline Jangada & $24.63 \pm 3.79 \mathrm{ab}$ & $0.00 \pm 8.39$ & $\mathrm{~S}$ & $96.50 \pm 7.97 b$ \\
\hline Nilo & $30.13 \pm 3.58 \mathrm{a}$ & $10.75 \pm 8.39$ & $\mathrm{St}$ & $84.75 \pm 7.11 b$ \\
\hline $\mathrm{F}$ & $11.25^{* *}$ & --- & --- & $11.98^{* *}$ \\
\hline CV $(\%)$ & 14.40 & --- & --- & 12.19 \\
\hline
\end{tabular}

${ }^{1}$ Means followed by the same letter in the column don't differ significantly, according to Tukey's test $(p<0,05)$; original data for analysis were transformed into $(x+0,5)^{1 / 2}$ (médias seguidas de mesma letra, dentro das colunas, não diferem entre si pelo teste de Tukey $(p<0,05)$; dados originais para análise foram transformados em $\left.(\mathrm{x}+0,5)^{1 / 2}\right) ;{ }^{2} \mathrm{OPI}=(\mathrm{T}-\mathrm{P}) /(\mathrm{T}+\mathrm{P}) \mathrm{x} 100$. Classification: $\mathrm{St}=\mathrm{stimulant} ; \mathrm{S}=\mathrm{standard} ; \mathrm{N}=$ neutral; $\mathrm{D}=$ deterrent. (classificação: $\mathrm{St}=$ estimulante; $\mathrm{S}=$ controle; $\mathrm{N}=$ neutro; $\mathrm{D}=$ deterrente).

populations of the insect.

The fact that one genotype was less infected by the whitefly may have resulted from the presence of physical resistance factors, such as leaf coloring, that can directly affect preference or even repel adults of the insect (Beck \& Schoonhoven, 1980; Coelho et al., 2009). Regardless of the cause (chemical or physical), the non-preference of $B$. tabaci biotype $\mathrm{B}$ for determined melon cultivar is a good management tool, because by preventing the insect from arriving on the plants, it also prevents oviposition and feeding that reduces the incidence of physiological disorders and virus transmission. These possible factors should be further investigated in future studies.

Regarding the mean of eggs laid/ $\mathrm{cm}^{2}$, 'Vereda', 'Amarelo Ouro' and 'AF646' were the least oviposited (Figure 1), indicating there was non-preference for oviposition. Probably, in consequence of this fact, 'Vereda' and 'AF-646' also presented the lowest $B$. tabaci biotype B nymph means (Figure 1).

In other plant species, researchers have reported that there are different levels of attractiveness and preference 
Table 3. Average period ( $\pm \mathrm{SE}$ ) of nymphal instars and total cycle (egg-adult) of $B$. tabaci biotype B obtained in nine melon cultivars in laboratory $\left(25 \pm 2^{\circ} \mathrm{C} ; 70 \pm 10 \% \mathrm{RH} ; 12: 12 \mathrm{~L}: \mathrm{D}\right.$ (médias $( \pm \mathrm{EP})$ de duração de ínstares ninfais e ciclo total (ovo-adulto) de $B$. tabaci biótipo B em nove cultivares de meloeiro em laboratório $\left(T=25 \pm 2^{\circ} \mathrm{C}\right.$; UR $=70 \pm 10 \%$; fotofase $=12 \mathrm{~h}$ ). Botucatu, UNESP, $2008 / 2009$.

\begin{tabular}{|c|c|c|c|c|c|}
\hline \multirow{2}{*}{ Cultivar } & \multicolumn{4}{|c|}{ Period (days) } & \multirow{2}{*}{ Total cycle } \\
\hline & $1^{\text {st }}$ instar & $2^{\text {nd }}$ instar & $3^{\text {rd }}$ instar & $4^{\text {th }}$ instar & \\
\hline Jangada & $4.20 \pm 0.15$ & $3.53 \pm 0.51$ & $3.36 \pm 0.50 \mathrm{ab}$ & $4.05 \pm 0.14 \mathrm{a}$ & $22.14 \pm 0.92$ \\
\hline Hales Best & $5.00 \pm 0.02$ & $2.60 \pm 0.03$ & $4.43 \pm 0.02 \mathrm{a}$ & $2.80 \pm 0.01 \mathrm{~b}$ & $21.83 \pm 0.02$ \\
\hline Frevo & $4.98 \pm 0.78$ & $3.65 \pm 0.12$ & $2.94 \pm 0.41 \mathrm{~b}$ & $3.03 \pm 0.38 \mathrm{~b}$ & $21.60 \pm 0.17$ \\
\hline AF-646 & $3.97 \pm 0.22$ & $3.40 \pm 0.11$ & $3.84 \pm 0.20 \mathrm{ab}$ & $3.17 \pm 0.03 \mathrm{ab}$ & $21.59 \pm 0.32$ \\
\hline Amarelo Ouro & $4.61 \pm 0.05$ & $3.83 \pm 0.19$ & $3.06 \pm 0.20 \mathrm{~b}$ & $2.92 \pm 0.24 \mathrm{~b}$ & $21.42 \pm 0.51$ \\
\hline Nilo & $4.80 \pm 0.25$ & $3.41 \pm 0.20$ & $2.88 \pm 0.19 b$ & $3.28 \pm 0.12 \mathrm{ab}$ & $21.37 \pm 0.35$ \\
\hline Vereda & $4.72 \pm 0.20$ & $3.33 \pm 0.22$ & $3.20 \pm 0.12 \mathrm{ab}$ & $3.03 \pm 0.15 b$ & $21.22 \pm 0.17$ \\
\hline Don Luis & $4.39 \pm 0.33$ & $3.32 \pm 0.24$ & $3.05 \pm 0.12 \mathrm{~b}$ & $3.21 \pm 0.25 \mathrm{ab}$ & $20.98 \pm 0.10$ \\
\hline AF-682 & $3.93 \pm 0.43$ & $3.78 \pm 0.40$ & $2.87 \pm 0.16 \mathrm{~b}$ & $3.21 \pm 0.14 \mathrm{ab}$ & $20.19 \pm 0.39$ \\
\hline $\mathrm{F}$ & $1.41^{\text {ns }}$ & $1.89^{\mathrm{ns}}$ & $4.22^{* *}$ & $3.42^{*}$ & $1.81^{\mathrm{ns}}$ \\
\hline $\mathrm{CV}(\%)$ & 13.23 & 13.34 & 13.43 & 10.54 & 3.35 \\
\hline
\end{tabular}

Original data; means followed by the same letter in the column don't differ significantly, according to Tukey's test ( $\mathrm{p}<0,05)$. (dados originais; médias seguidas de mesma letra, dentro das colunas, não diferem entre si pelo teste de Tukey $(\mathrm{p}<0,05)$.

for oviposition by B. tabaci biotype B, depending on the genotypes used. In a field trial with squash cultivars, Baldin et al. (2009) reported that the Sandy cultivar was the least attractive to the whitefly, while Caserta Cac Melhorada was the least oviposited. In a greenhouse assay, Valle \& Lourenção (2002) reported large differences regarding the attractiveness of soybean genotypes for this whitefly, and 'IAC 17' and 'IAC 19' were considered the least attractive. Boiça Júnior et al. (2007) assessed the attractiveness and oviposition preference on 21 cotton genotypes, and found a significant gradient among the materials, especially for 'Fabrika', described as the least attractive and oviposited in free-choice and nochoice tests. Fancelli et al. (2003) also observed great variability in tomato plant attractiveness and even absence of infestation in wild Solanum species.

Greenhouse trials - The 'Hales Best' was outstanding in the free-choice test with the least number of adults per plant in the assessments at 24 and 48 hours after infestation, showing that it was the least attractive to $B$. tabaci biotype $\mathrm{B}$ (Table 1). In contrast, 'Jangada' and 'AF-646', 'AF-682' (24 and $48 \mathrm{~h}$ ) and 'Frevo' (48 h) were the most attractive to the adults. The low attractiveness observed in 'Hales Best' in the greenhouse corroborated the field results obtained with this material (Table 1) and confirmed there was nonpreference for this material. 'AF-682' was considered not very attractive in the field, but the greenhouse data indicated it to be the most attractive in this type of trial. This contrast may have been related to the lower infestation of the insect observed in the field and may also be due to the influence of abiotic factors, as discussed by Lourenção et al. (2011).

Regarding the number of eggs laid on the leaves of the cultivars in the freechoice test (Table 1), 'Amarelo Ouro' presented the lowest mean, suggesting oviposition non-preference. Based on the oviposition preference index, the 'Amarelo Ouro', 'Hales Best', 'Don Luis', 'Nilo', 'AF-646' and 'Frevo' were deterrent compared to the susceptible control 'Jangada'. In a similar trial, with 32 different melon cultivars, 'Jangada' also stood out as among the most attractive and oviposited by $B$. tabaci biotype B, while 'Neve' was the most resistant (Coelho et al., 2009).

In a no choice test, the 'Amarelo Ouro', 'Hales Best', 'AF-646' and 'Vereda' were the least oviposited by whitefly, unlike 'Nilo' and 'Jangada' (Table 2). Based on the index, these four cultivars and also 'AF-682' were deterrent to oviposition from whitefly when compared to the commercial control 'Jangada'. 'Don Luis' and
'Frevo' were neutral while 'Nilo' stimulated the oviposition corroborating data by Coelho et al. (2009), who also identified this cultivar as the most ovipositioned together with 'Jangada'. The low means of eggs laid on the leaves of the 'Amarelo Ouro' and 'Hales Best' cultivars corroborated the results of the free-choice test (Table 1) and indicated there was oviposition non-preference on these materials.

Research has demonstrated that leaf position on the plant can play an important role in the choice of oviposition location for B. tabaci biotype B (Chu et al., 1995; Liu \& Stansly, 1995; Baldin \& Pereira, 2009). In and experiment with Cucurbita spp. genotypes, Baldin \& Beneduzzi (2010) assessed the interaction between the leaf position on the plant and the number of eggs deposited by the whitefly and observed that there was less oviposition when the leaves were in a higher position on the plant. The same was reported by Cardoza et al. (1999), who observed less oviposition on the abaxial surface of upper leaves of the Elite, ZUC76-SLR and ZUC33-SLR/PMR genotypes.

Further on whitefly oviposition, morphological aspects of the plant, such as trichome density and configuration (glandular or not), can represent important resistance sources (Toscano 


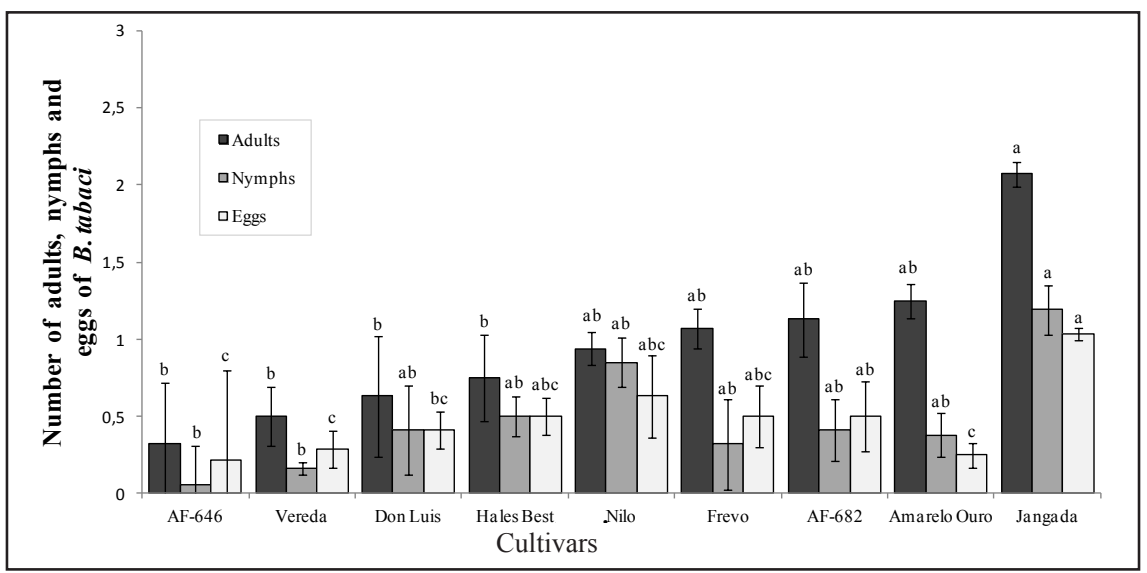

Figure 1. Mean $( \pm \mathrm{SE})$ number of adults, eggs and nymphs of $B$. tabaci biotype $\mathrm{B}$ on melon plants, obtained during the development of culture in the field (número médio $( \pm \mathrm{EP}) \mathrm{de}$ adultos, ovos e ninfas de B. tabaci biótipo B por planta de melão, obtidos durante ensaio de campo). Botucatu, UNESP, 2008/2009.

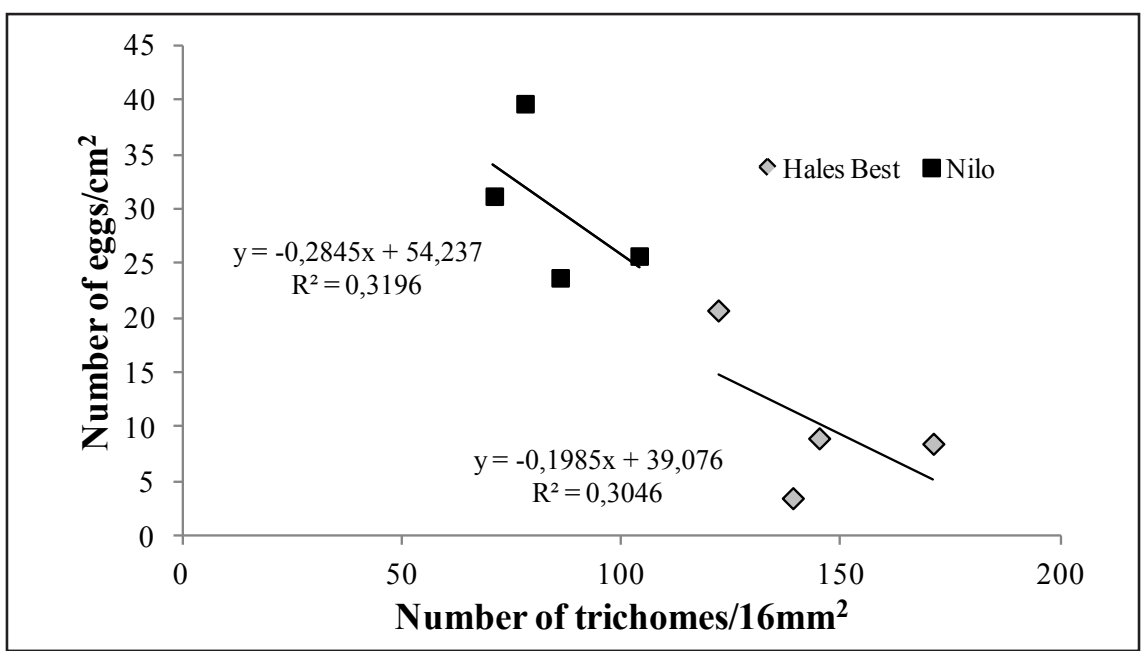

Figure 2. Correlation between mean of trichome $/ 16 \mathrm{~mm}^{2}$ and number of eggs $/ \mathrm{cm}^{2}$ on 'Hales Best' and 'Nilo' cultivars (correlação entre a média de tricomas $/ 16 \mathrm{~mm}^{2}$ e o número de ovos/ $\mathrm{cm}^{2}$ presentes nas cultivares 'Hales Best' e 'Nilo'). Botucatu, UNESP, 2008/2009.

et al., 2002a; 2002b). The trichome quantification in the present study (no choice test) showed that the 'Hales Best' cultivar had the highest trichome density compared to the other cultivars (Table 2). The correlation graph (Figure 2) between trichome density and number of eggs on 'Hales Best' and 'Nilo' suggested that as the number of trichomes increased, whitefly oviposition rate decreased. However, considering other materials such as 'Amarelo Ouro', this tendency was not confirmed, suggesting the action of other factors. Generally high B. tabaci biotype $\mathrm{B}$ oviposition rates have been associated to high trichome densities on soybean, cotton and tomato leaves (Valle \& Lourenção, 2002;
McAuslane 1996; Heinz \& Zalom, 1995; Flint \& Parks, 1990). The negative correlation observed between trichomes and oviposition for some of the cultivars assessed in the present study can be explained by the low variability in trichome density in the germplasm assessed.

The presence of glandular trichomes is considered one of the main causes of morphological resistance in plants and can affect oviposition and feeding of small sucking insects (Sippell et al., 1987; Heinz \& Zalom, 1995; McAuslane, 1996). The importance of these structures as resistance source against whitefly has been reported by several authors (Butler Junior et al.,
1986; Valle \& Lourenção, 2002; Lima \& Lara, 2004; Fancelli et al., 2003; Baldin et al., 2005). The potential effects of the trichomes on the whitefly can vary, favoring or not the insect, depending on the trichome angle on the leaf surface, length and type. These factors potentially affect oviposition, fixing and juvenile feeding (Mound, 1965; Williams et al., 1980; Channarayappa et al., 1992). The morphological and chemical characterization of the trichomes in melon cultivars should be assessed in greater depth in future studies, to help in the understanding of the interaction with $B$. tabaci biotype B.

Significant differences were not detected among the cultivars regarding the duration of the first and second nymph instars (Table 3 ). Regarding the third instar, 'Hales Best' significantly prolonged the period, differing from 'Frevo', 'Nilo', 'Amarelo Ouro', 'Don Luis' and 'AF-682'. In the fourth nymph instar, the Jangada cultivar differed from 'Hales Best', 'Frevo', 'Vereda' and 'Amarelo Ouro' and presented the highest mean duration compared to the other genotypes. The significant prolongation observed in 'Hales Best' and 'Jangada', in the third and fourth instars, respectively, suggested there was non-preference for feeding and/or antibiosis (Panda, 1979; Lara, 1991). However, as the cultivars did not differ for the total B. tabaci biotype B development period (egg-adult), it can be stated that these resistance mechanisms occurred at low levels.

Coelho et al. (2009) in a similar experiment with the same whitefly species, did not observe significant differences in the development periods of seven melon cultivars. These authors reported means ranging from 24.0 and 25.4 days, that is, they were almost 5 days longer than those obtained in the present study. This probably occurred because the trial was carried out in a greenhouse and not a laboratory, as in the present study. The means of adult emergence in the present study were around $80 \%$, with no significant difference among the cultivars. Among the seven cultivars assessed by Coelho et al. (2009), 'Vereda' (68.25\%) and 'Nilo' $(69.3 \%)$ presented the lowest emergence 
means, indicating there was antibiosis in these materials.

Based on all the assessments carried out, 'Hales Best' and 'Amarelo Ouro' were the most resistant cultivars, expressing oviposition non-preference to whitefly. The trichome density was associated to variation in oviposition on the materials and should be better investigated in future studies. These results can be useful in melon breeding programs to obtain cultivars resistant to $B$. tabaci biotype $\mathrm{B}$ in the field and greenhouse.

\section{REFERENCES}

AGRIANUAL 2011: Anuário Estatístico da Agricultura Brasileira. 2011. São Paulo: FNP - Consultoria \& Agroinformativos, p. 482.

ALVES AC; LOURENÇÃO AL; MELO AMT. 2005. Resistência de genótipos de aboboreira a Bemisia tabaci (Genn.) biótipo B (Hemiptera: Aleyrodidae). Neotropical Entomology 34: 973-979.

AZEVEDO FR; BLEICHER E. 2003. Distribuição vertical e setorial das ninfas de moscabranca nas folhas do meloeiro. Horticultura Brasileira 21: 464-467.

BALDIN ELL; VENDRAMIM JD; LOURENÇÃO AL. 2005. Resistência de genótipos de tomateiro à mosca-branca Bemisia tabaci (Gennadius) Biótipo B (Hemiptera: Aleyrodidae). Neotropical Entomolgy 34: 435-441.

BALDIN ELL; BENEDUZZI RA; SOUZA DR; SOUZA ES. 2009. Resistência de genótipos de abobrinha a Bemisia tabaci (Genn.) Biótipo B (Hemiptera: Aleyrodidae). Neotropical Entomology 38: 526-530.

BALDIN ELL; PEREIRA JM. 2009. Influência da altura de folíolos na expressão da resistência de genótipos de tomateiro a Bemisia tabaci (Genn.) biótipo B (Hemiptera: Aleyrodidae). Boletín de Sanidad Vegetal Plagas 35: 249258.

BALDIN ELL; BENEDUZZI RA. 2010. Characterization of antibiosis and antixenosis to the whitefly silverleaf Bemisia tabaci B biotype (Hemiptera: Aleyrodidae) in several squash varieties. Journal of Pest Science 83: 223-229.

BECK SD; SCHOONHOVEN LM. 1980. Insect behavior and plant resistance. In: MAXWELL FG; JENNINGS PR (eds). Breeding plants resistant to insects. New York: John Wiley \& Sons. p. 116-135.

BLEICHER E; MELO QMS; SOBRAL ARA. 2000. Uso de inseticidas seletivos no controle de mosca-branca no meloeiro. Horticultura Brasileira 18: 359-360.

BLEICHER E; GONÇALVES MEC; SILVA LD. 2007. Efeito de derivados de nim aplicados por pulverização sobre a mosca-branca em meloeiro. Horticultura Brasileira 25: 110-113.
BOIÇA JÚNIOR AL; CAMPOS ZR; LOURENÇÃO AL; CAMPOS AR. 2007. Adult attractiveness and oviposition preference of Bemisia tabaci (Genn.) (Homoptera: Aleyrodidae) B-biotype in cotton genotypes. Scientia Agricola 64: 147-151.

BUTLER JUNIOR GD; HENNEBERRY TJ; WILSON FD. 1986. Bemisia tabaci (Homoptera: Aleyrodidae) on cotton: adult activity and cultivar ovipostion preference. Journal of Economic Entomology 79: 350-354.

BYRNE FJ; CASTLE S; PRABHAKER N; TOSCANO NC. 2003. Biochemical study of resistance to imidacloprid in B biotype Bemisia tabaci from Guatemala. Pest Management Science 59: 347-352.

CARDOZA YJ; McAUSLANE HJ; WEBB SE. 1999. Mechanisms of resistance to whitefly-induced squash silverleaf disorder in Cucurbita pepo L. Journal of Economic Entomolgy 92: 700-707.

CHANNARAYAPPA SG; MUNIYAPPA V; FRIST RH. 1992. Resistance of Lycopersicon species to Bemisia tabaci, a tomato leaf curl virus vector. Canadian Journal of Botany 70: 84-92

CHU CC; HENNEBERRY TJ; COHEN AC. 1995. Bemisia argentifolii (Homoptera: Aleyrodidae) on cotton: host preference and factors affecting oviposition and feeding site preference. Annals of Entomological Society of America 94: 354-360.

COELHO AMP; LOURENÇÃO AL; MELO AMT; SCHAMMASS EA. 2009. Resistência de meloeiro a Bemisia tabaci biótipo B. Bragantia 68: 1025-1035.

DARDON SD. 1993. Las moscas blancas en Guatemala. In: HILJE L; ARBOLEDA O (eds). Las moscas blancas (Homoptera: Aleyrodidae) en America Cental y El Caribe. Turrialba: Catie. p. 38-41.

DESNEUX N; DECOURTYE A; DELPUECH JM. 2007. The sublethal effects of pesticides on beneficial arthropods. Annual Review of Entomology 52: 81-106.

DITTRICH VS; ERNST GH. 1990. Chemical control and insecticide resistance of whiteflies. In: GERLING D (ed). Whiteflies: their bionomics, pest status and management. Andover: Intercept. p.263-284.

FANCELLI M.; VENDRAMIM JD; LOURENÇÃO AL; DIAS CTS. 2003. Atratividade e preferência para oviposição de Bemisia tabaci (Gennadius) (Hemiptera: Aleyrodidae) biótipo B em genótipos de tomateiro. Neotropical Entomology 32: 319-328.

FAO - Food and Agriculture Organization of the United Nations. 2006. 30 de novembro. Agricultural production, primary crops. Disponível em http://www.fao.org/

FENEMORE PG. 1980. Oviposition of potato tuber moth, Phthorimaea operculella Zell. (Lepidoptera: Gelechiidae); identification of host-plant factors influencing oviposition response. Journal of Zoology 7: 435-439.

FLINT HM; PARKS NJ. 1990. Infestation of germplasm lines and cultivars of cotton in Arizona by whitefly nymphs (Homoptera: Aleyrodidae). Journal of Entomological
Science 25: 223-229.

FONTES FHM; COLOMBO CA; LOURENÇÃO AL. 2010. Caracterização molecular e divergência genética de Bemisia tabaci (Genn.) (Hemiptera: Aleyrodidae). Neotropical Entomology 39: 221-226.

HEINZ KM; ZALOM FG. 1995. Variation in trichome-based resistance to Bemisia argentifolii (Homoptera: Aleyrodidae) oviposition on tomato. Journal of Economic Entomology 88: 1494-1502.

LARA FM. 1991. Princípios de resistência de plantas a insetos. São Paulo: Ícone. 336p.

LIMA ACS; LARA FM. 2004. Resistência de genótipos de soja à mosca-branca Bemisia tabaci biótipo B (Hemiptera: Aleyrodidae). Neotropical Entomology 33: 71-75.

LIU TX; STANSLY PA. 1995. Toxicity of biorational insecticides to Bemisia argentifolii (Homoptera: Aleyrodidae) on tomato leaves. Journal of Economic Entomology 88: 564-568.

LOURENÇÃO AL; ALVES AC; MELO AMT; VALLE GE. 2011. Development of leaf silvering in squash cultivars infested by silverleaf whitefly. Horticultura Brasileira 29: 112-116.

LOURENÇÃO AL; VENDRAMIM JD; FUGI CGQ; VALLE GE. 2011. Resistência de plantas de importância econômica à mosca-branca Bemisia tabaci biótipo B. In: BALDIN ELL; FUJIHARA RT; FIRMINO AC; NEGRISOLI E; SOUZA ES; PRADO EP; MARUBAYASHI (eds). Avanços em fitossanidadae. Botucatu: Fepaf. p.33-54.

MANSARAY A; SUNDUFU AJ. 2009. Oviposition, development and survivorship of the sweetpotato whitefly Bemisia tabaci on soybean, Glycine max, and the garden bean, Phaseolus vulgaris. Journal Insect Science. Disponível em http://www.insectscience. org/9.01. Acessado em 29 de abril de 2011.

McAUSLANE HJ. 1996. Influence of leaf pubescence on ovipositional preference of Bemisia argentifolii (Homoptera: Aleyrodidae) on soybean. Environmental Entomology 25: 834-841.

MOUND LA. 1965. Effects of leaf hair on cotton whitefly populations in the Sudan Geriza. 1965. The Empire Cotton Growing Review 42:33-40.

NAGATA T; ALVES DMT; IONUE-NAGATA AK; TIAN TY; KITAJIMA EW; CARDOSO JE; ÁVILAAC. 2005. A novel melon flexivirus transmitted by whitefly. Archives of Virology 150: $379-387$.

PANDA N. 1979. Principles of host-plant resistance to insect pests. New York: Osmun. $386 \mathrm{p}$.

PERRING TM; COOPER AD; RODRIGUEZ RJ; FARRAR CA; BELLOWS JUNIOR TS. 1993. Identification of a whitefly species by genomic and behavioral studies. Science 259: 74-77.

POLSTON JE; ANDERSON PK. 1999. Surgimiento y distribución de geminivírus transmitidos por mosca blanca en tomate en el hemisferio occidental. Manejo Integrado de Plagas 53: 24-42.

PRABHAKER N; TOSCANO NC; COUDRIET DL. 1989. Susceptibility of the immature 
and adult stages of the sweetpotato whitefly (Homoptera: Aleyrodidae) to selected inseticides. Journal of Economic Entomology 82: 983-988.

RILEY DG; PALUMBO JC. 1995. Interaction of silverleaf whitefly (Homoptera: Aleyrodidae) with cantaloupe yield. Journal of Economic Entomology 88: 1726-1732.

SCHILICK-SOUZA EC; BALDIN ELL; LOURENÇÃO AL. 2011. Variation in the host preferences and responses of Ascia monuste orseis Godart (Lepidoptera: Pieridae) to cultivars of collard greens Brassica oleracea (L.) var. acephala. Journal of Pest Science 84: 429-436.
SILVA MS; LOURENÇÃO AL; SOUZA-DIAS JAC; MIRANDA FILHO HS; RAMOS VJ; SCHAMMASS EA. 2008. Resistance of potato genotypes (Solanum spp.) to Bemisia tabaci biotype B. Horticultura Brasileira 26: 221-226

SIPPEL DW; BINDRA OS; KHALIFA H. 1987. Resistance to whitefly (Bemisia tabaci) in cotton (Gossypium hirsutum) in the Sudan. Crop Protection 6: 171-178.

TOSCANO LC; BOIÇA JÚNIOR AL; MARUYAMA WI. 2002a. Non-oviposition preference of whitefly for tomato genotypes. Scientia Agricola 54: 677-681.

TOSCANO LC; BOIÇA JÚNIOR AL;
MARUYAMA WI. 2002b. Fatores que afetam a oviposição de Bemisia tabaci (Genn.) biótipo B (Hemiptera: Aleyrodidae) em tomateiro. Neotropical Entomology 31: 631-634.

VALLE GE; LOURENÇÃO AL. 2002. Resistência de genótipos de soja a Bemisia tabaci (Genn.) biótipo B (Hemiptera: Aleyrodidae). Neotropical Entomology 31: 285-295.

WILLIAMS WG; KENNEDY GG; YAMAMOTO RT; TRACKER JD; BORDNER J. 1980. 2-Tridecanone: a naturally occurring insecticide from the wild tomato, Lycopersicon hirsutum f. glabratum. Science 207: 888-889.

WINER BJ; BROWN DR; MICHELS KM. 1991. Statistical principles in experimental design. New York: MacGraw-Hill. 1057p. 